Transactions of the Karelian Research Centre of the Russian Academy of Sciences

No. 2. 2020. P. 18-33

DOI: $10.17076 /$ geo1185
Труды Карельского научного центра РАН

№ 2. 2020. C. 18-33

УДК 551.242.5:551.71/.72(474.2)

\title{
THE EVOLUTION OF THE ESTONIAN PRECAMBRIAN BASEMENT: GEOLOGICAL, GEOPHYSICAL AND GEOCHRONOLOGICAL CONSTRAINTS
}

\author{
A. Soesoo', S. Nirgi',2, J. Plado' \\ ${ }^{1}$ University of Tartu, Institute of Ecology and Earth Sciences, Department of Geology, Estonia \\ ${ }^{2}$ Geological Survey of Estonia
}

\begin{abstract}
The Estonian Precambrian crystalline basement, which consists of Paleo- to MesoProterozoic metamorphic and igneous rocks, is covered by a $100-780 \mathrm{~m}$ thick deposit of Paleozoic sedimentary rocks. Thus, the basement is unavailable for direct observations from the surface, and our present knowledge is based on information from cores of deep drillings and interpretation of potential - gravity and magnetic - fields. Accordingly, the basement of Estonia is subdivided into two major geological units - North Estonian amphibolite and South Estonian granulite complexes. Further division includes six structural-petrological zones such as Tallinn, Alutaguse, Jõhvi, West-Estonian, Tapa and South-Estonian zones. This article provides an updated overview of the Estonian Precambrian basement, its rock types, geophysical fields, geochronology, metamorphism and metallogenesis.
\end{abstract}

Ke y w o rd s: Proterozoic; igneous and metamorphic rocks; geochronology; geophysics; metallogenesis; Estonian basement.

\section{А. Соэсоо, С. Нирги, Ю. Пладо. ЭВОЛЮЦИЯ ЭСТОНСКОГО ДОКЕМ- БРИЙСКОГО КРИСТАЛЛИЧЕСКОГО ФУНДАМЕНТА: ГЕОЛОГИЧЕСКИЕ, ГЕОФИЗИЧЕСКИЕ И ГЕОХРОНОЛОГИЧЕСКИЕ ОГРАНИЧЕНИЯ}

Докембрийский кристаллический фундамент Эстонии, состоящий из метаморфических и магматических пород от палео- до мезопротерозоя, перекрыт чехлом осадочных палеозойских отложений мощностью 100-780 м. Так как кристаллический фундамент недоступен для прямого изучения на поверхности Земли, наши нынешние знания основаны на данных глубинного бурения и геофизики (интерпретации гравитационного и магнитного полей). Кристаллический фундамент Эстонии делится на две крупные геологические единицы - Северо-Эстонский амфиболитовый и Южно-Эстонский гранулитовый комплексы. Дальнейшее деление включает шесть структурно-петрологических зон, таких как Таллиннская, Алутагузе, Йыхви, Западно-Эстонская, Тапа и Южно-Эстонская. В данной статье представлен обновленный обзор докембрийского фундамента Эстонии, типов слагающих его горных пород, геофизических полей, геохронологии, метаморфизма и металлогенеза.

Ключевые слова: протерозой; магматические и метаморфические породы; геохронология; геофизика; металлогенез; кристаллический фундамент Эстонии. 


\section{Introduction}

The Precambrian crystalline basement of Estonia is covered by a $100-780 \mathrm{~m}$ thick deposit of Paleozoic sedimentary rocks. The basement consists of Paleo- to Meso-Proterozoic metamorphic and igneous rocks. Since there are no outcrops of the crystalline basement rocks, drill core material, geophysical and geochemical methods were used for geological reconstructions. More than sixty years of research have led to a number of publications and reports (before the $1990^{\text {th }}$, the publications were mostly in Russian), and one monograph [Puura et al., 1983], in addition to several regional geological maps [Grigelis and Puura, 1978; Puura, 1980; Koistinen, 1994]. Based on these investigations, the 1:400000 scale geological map of the crystalline basement of Estonia was compiled [Koppelmaa, 2002]. The map was based on the results of integrated (petrographical, petrophysical and geochemical) investigations of 32500 metres of drill-cores from ca 490 holes and data from gravimetric and magnetometric surveys. In the $1990^{\text {th }}$, a number of articles dealing with general geology [Soesoo, 1991; Petersell and Levchenkov, 1994], geochronology [Petersell, 1991; Puura and Huhma, 1993], metamorphism [Höltta and Klein, 1991], post-orogenic rocks [Soesoo and Niin, 1992; Soesoo, 1993; Kirs and Petersell, 1994; Rämö et al., 1996; Puura and Floden, 1996, 1999, 2000], and partial melting and migmatization [Soesoo et al., 2004a, b, 2006] were published. A special issue, compiling papers on a wide range of geological aspects of the Estonian Precambrian was published in 2004 (Proceedings of Estonian Academy of Sciences, Geology, No. 53, Editor: A. Soesoo).

In the uppermost section of the Estonian basement there is an ancient, dominantly kaolinitic (together with montmorillonite and illite) weathering crust with thickness ranging from a few meters to several tens of meters. Due to intense denudation during the late Proterozoic, the surface of the basement has turned into a peneplane, which dips gently (average $0.10-0.20^{\circ}$, i. e. 2-3.5 $\mathrm{m}$ per $\mathrm{km}$ ) southward (SSE - SSW; $150-200^{\circ}$ ). On Vaindloo Island (Gulf of Finland) the crystalline basement lies at a depth of $67.5 \mathrm{~m}$, on Juminda Peninsula at $103.5 \mathrm{~m}$ and $629.0 \mathrm{~m}$ in Häädemeeste (SW Estonia), and at $784.1 \mathrm{~m}$ on Ruhnu Island (Gulf of Riga). The relatively level surface of the basement is interrupted by erosional relief forms, escarpments generated by tectonic disturbances, dome-shaped uplifts such as Sonda - Uljaste, Assamalla in NE Estonia and Mõniste Uplift in SE Estonia. The rim walls of the Kärdla impact crater on Hiiumaa Island and Neugrund cra- ter near Osmussaar Island also appear as positive landforms.

Based on the findings of geophysical and petrological studies, the Estonian basement can be divided into two major geological units - the North Estonian amphibolite facies unit and the South Estonian granulite facies unit, which are separated from one another by a tectonic boundary - Paldiski-Pskov tectonic (shear) zone (PPDZ; Fig. 1). The basement includes six structural-petrological zones such as Tallinn, Alutaguse, Jõhvi, West-Estonian, Tapa and South-Estonian zones (Fig. 1). These zones differ in rock composition, genesis, geophysical properties, and degree of metamorphism. The aim of this paper is to present an updated overview of the Estonian Precambrian basement, its rock types, geophysical fields, geochronology and metamorphism.

\section{History of Precambrian studies and the position of the Estonian basement within the Fennoscandian orogenic system}

A. Öpik [1942] was likely the first scientist to propose that the Estonian basement belongs to the Svecofennian orogenic system in the Fennoscandian Shield. From the 1950's to the 1990's, geologists departed from this idea and suggested that higher grade metamorphism, which is usually complemented by high geophysical anomalies, in South Estonia, Latvia, Lithuania and NW Belarus can be correlated to several other high-grade metamorphic complexes in East and NE Europe, and thus can be considered to be of Archaean age [Puura et al., 1976; Gorbatschev and Gaal, 1987]. Subsequent studies of Estonian crystalline rocks in the 1960's - 1980's [e. g., Puura et al., 1983 and references therein] have corroborated that at least the basement of North Estonia is a part of the large Archaean-Proterozoic Fennoscandian (Baltic) Shield (continuation of the Svecofennian orogenic zone). However, there was no direct evidence how far the shield rocks extend towards the south. Until the late 1980's, geologists believed that the granulitic rocks of the South Estonian complex were Archaean, or at least pre-Svecofennian in age [Puura et al., 1983; Gorbatschev and Gaal, 1987]. This assumption was based on lithological correlations of granulitic facies rocks with those of the Kola series [Bondarenko and Dagelaiskii, 1968] and on the idea that regional granulite facies rocks should be older than their lower grade counterparts.

However, the results of $\mathrm{Sm}-\mathrm{Nd}$ and $\mathrm{U}-\mathrm{Pb}$ isotopic studies [Huhma et al., 1991a, b; Puura and Huhma, 1993; Petersell and Levchenkov, 1994] suggested that the South Estonian granu- 

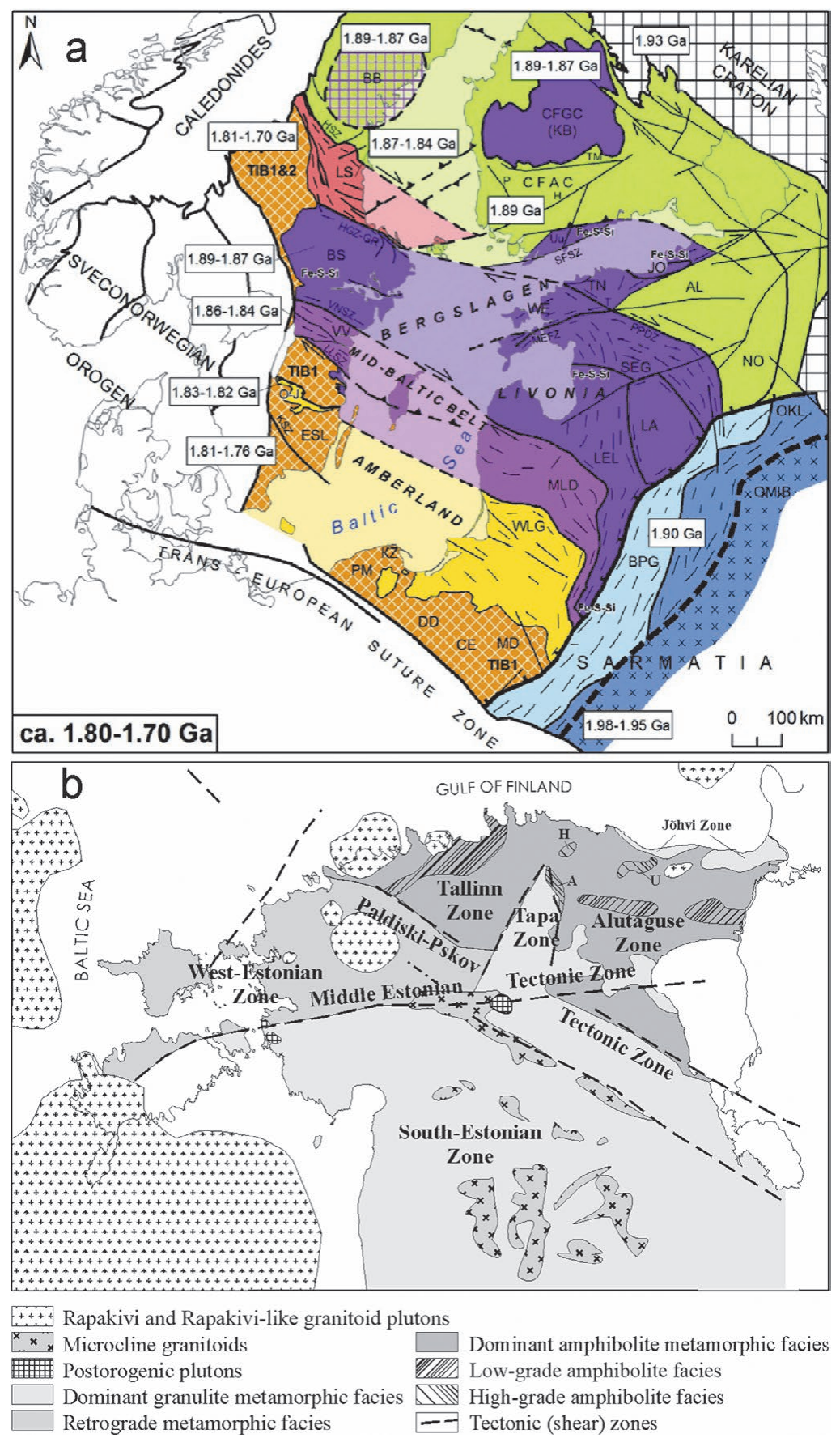

Fig. 1. (a) Position of the Estonian Precambrian basement within the Fennoscandian-Baltic tectono-geological crustal structure [as in: Bogdanova et al., 2015]. Two large units - magmatic-volcanic-sedimentary BergslagenLivonia "microcontinent" and a large sedimentary Al-gneisses block constitute the Estonian basement. The ages in the frames are those of the principal accretionary events in the indicated domains. The abbreviations for tectonic domains are: $\mathrm{AL}$ - Alutaguse, $\mathrm{BB}$ - Bothnian (Bothnia microcontinent), BS - Bergslagen (Bergslagen microcontinent), BPG - Belarus-Podlasie granulite belt, CE - Ciechanow, CFAS - Central Finland Arc Complex; CFGC-Central Finland Granitoid Complex (Keitele microcontinent), DO - Dobrzyn, ESL - East Smäland, JO - Jõhvi, KB - Keitele microcontinent, KZ - Kaszuby, LA - Latgalia, LEL-Latvian-East Lithuanian, LGB - Lapland Granulite Belt, LKO Lapland-Kola orogen, LS - Ljusdal, MD-Mazowsze, MLD-Mid-Lithuanian domain, NB - Norrbotten, NO - Novgorod, OKL - Okolovo, OMIB - Osnitsk- Mikashevichi Igneous Belt, PM - Pomorze, SEG - South Estonian granulite domain, T - Tapa, TN - Tallinn, Uu - Uusimaa, VV-Västervik, WE - West Estonian domain, WLG - West Lithuanian granulite domain. Deformation zones: HGZ-GR - Hagsta-Gävle-Rättvik Zone, HSZ - Hassela Shear Zone, KSZ - Karlskrona Shear zone; LLSZ - Linköping-Loftahammar Shear Zone, MEFZ - Middle Estonian Fault Zone, PPDZ - Paldiski-Pskov Deformation Zone, SFSZ - South Finland Shear Zone, VNSZ - Vingäker-Nyköping Shear Zone, and for volcanic belts and sedimentary basins: H - Häme, Mk - Monki, O-J - Oskarshamn-Jönköping, P - Pirkanmaa, Pc - Poceai, Sc Salcia, Tm - Tampere; (b) Geological-structural zones of the Estonian Precambrian basement 
lites are more likely early Proterozoic than Archean in age. The studied granulites yielded mantle extraction model ages of about $2 \mathrm{Ga}$, which is younger than Archaean, but somewhat older than typical Svecofennian rocks in southern Finland and Sweden.

Based on petrographic and geochemical similarities, the North Estonian amphibolite facies rocks were believed to belong to a section of Svecofennian rocks cropping out in Southern Finland. This view has remained unchanged. More studies were needed to establish the structural-geological position of the South Estonian granulites. Two case studies focusing on the metamorphism of granulite zones have been performed [Hölttä and Klein, 1991; Kikas, 2001] and a compilation on the general features of metamorphism was produced [Puura et al., 2004]. New isotopic studies confirmed the Proterozoic ages of Estonian granulites [Soesoo et al., 2006].

Ideas about the magmatic and tectonic evolution of the Svecofennian Orogen have changed during the last decades. Hietanen [1975] proposed a model which explains rock variations in the Fennoscandian Shield by opening of an oceanic basin, subduction and island arc magmatism. More recent and complex magmatic and tectonic models have been proposed by Baker et al. [1988], Gaal [1990], Park [1991], Lahtinen [1994], and Nironen [1997]. In the recent models, the evolution of the Svecofennian Domain is interpreted as multiple, time- and space-dependent subduction-related collisions of several island-arc structures. It is thought that the $1.91-1.8 \mathrm{Ga}$ magmatism and metamorphism were related to these collisions. A new advanced and detailed Trans-Scandinavian-Baltic compilation has been published by Bogdanova et al. [2015].

The nature of potential geophysical fields in Estonian territory has been studied since the early 1950's, when Fotiadi [1958] provided the structural zonation of the basement on the basis of magnetic and gravity fields. The rationale is that potential fields display the structure of the crystalline basement whereas the effect of the overlying sedimentary cover is minor. Ideas about the sources for different types of geophysical anomalies have, however, changed several times according to the incoming data from additional deep drillings [Puura, 1980; Puura et al., 1983; Ankudinov et al., 1994].

\section{Geological features of geological zones of the Estonian Precambrian basement}

The crystalline basement of Estonia comprises Palaeoproterozoic metamorphic and igneous rocks, and a Subjotnian (late Palaeoproterozoic to early Mesoproterozoic) population of Rapakivi granite-type rock suites. The ca. $30 \mathrm{~km}$ wide, NW-trending PPDZ separates the structural domains in northern and north-eastern Estonia from those in the west and the south of Estonia (Fig. 1). It comprises two principal sub-parallel shear zones dipping between $65^{\circ}$ and $75^{\circ}$ SSW [All et al., 2004], features strong deformation, and contain slivers of both granulite- and amphibolite-facies rocks.

The PPDZ is well exhibited in gravity (Fig. 2) and magnetic (Fig. 3) fields by a combination of elongated local positive and negative anomalies. The structural domains north and south from the tectonic zone were, according to their anomaly patterns, initially [Fotiadi, 1958] named as North Estonian Geophysical Low and Baltic-Belarus Geophysical High, respectively. North of the tectonic zone, rocks with their relatively low density and magnetization cause local negative gravity and magnetic anomalies. Also, the fields are relatively smooth with rare short-wavelength anomalies. South of the tectonic zone, the high density and magnetization of granulites produce local positive anomalies and relatively high gradients, which are especially outstanding in magnetic field data (Fig. 3).

On the basis of previous geophysical and petrological studies, six geological zones are distinguished within these two units: Tallinn, Tapa, Alutaguse and Jõhvi zones (located north of the PPDZ), and the West-Estonian and South-Estonian zones (located south of the PPDZ; Fig. 1) [Puura et al., 1983; Koistinen, 1994; Soesoo et al., 2004a]. These zones mostly differ in rock assemblages (with metasedimentary or metavolcanic/-igneous origin), metamorphic grade and petrophysical properties of rocks, reflected in their potential fields.

The Tallinn Zone is characterised by negative free-air gravity and magnetic fields. The zone is bordered by a regional PPDZ in the southeast, which separates it from the West-Estonian Zone. Another less prominent tectonic disturbance zone separates the Tallinn Zone from the Tapa Zone in the east. The rocks of the Tallinn zone vary from mafic amphibolite facies metavolcanites to metasediments represented by amphibole gneisses, biotite-plagioclase gneisses, quartz-feldspar gneisses, mica gneisses, and minor sulphide-graphite gneisses and magnetite quartzites (Jägala complex). Migmatisation is generally common and locally strong. The Tallinn Zone may represent a volcanic arc that continues in the Uusimaa belt in Finland [Kähkönen, 2005].

East of the Tallinn Zone, the Alutaguse Zone and the smaller Jõhvi Zone are distinguished 


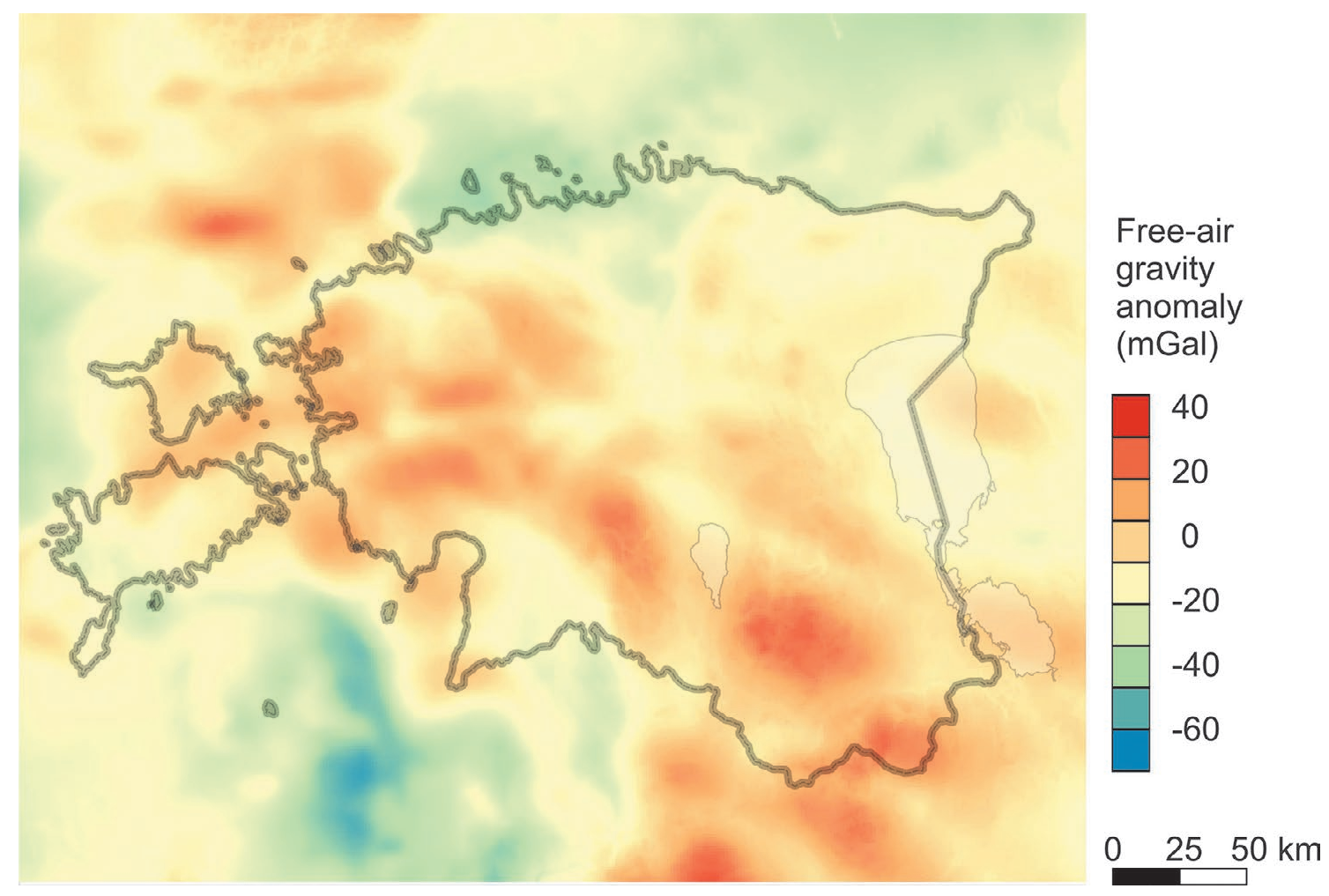

Fig. 2. Free-air gravity anomaly model. The map is based on the Estonian Gravity Database that was recently published by Oja et al. [2019] (Fig. 11). Raw data include 31,850 high-quality gravity points covering mainland and islands. International cooperation and marine survey projects have resulted in additional 17,339 points

(Fig. 1). The Alutaguse zone is characterised by near-zero free-air gravity and slightly negative magnetic anomalies. Local positive anomalies appear in the area of Sonda - Uljaste and Assamalla dome-like structures, Haljala and Luusika [Dmitrieva et al., 2018] area, which are associated with sulphide-graphite gneisses (black schists), quartzites, skarned carbonaceous rocks and pyroxene gneisses. The main rock types of the Alutaguse Zone are Al-rich gneisses (with biotite, cordierite, garnet, sillimanite) and biotite-plagioclase gneisses, less abundant are amphibole gneisses, amphibolites and quartz-feldspar gneisses. The rocks of the Alutaguse zone have metamorphosed under the amphibolite facies conditions. In some places (Sonda - Uljaste and Haljala) the rocks show evidence of granulite facies metamorphism. Migmatisation is common and locally strong.

The mostly metasedimentary Alutaguse Zone may be a part of the Kalevian-age marginal basin, which extends to the vicinity of St. Petersburg in Russia and farther east to Lake Ladoga [Bogdanova et al., 2015]. The deposition of turbidites in that basin has been estimated to have taken place between 1.96 and $1.90 \mathrm{Ga}$ [Lahtinen et al., 2010; Melezhik and Hanski, 2012]. However, the ages of deposition and metamorphism of the Alutaguse metasedimentary sequence are still unknown. Bogdanova et al. [2015] has noted that similar turbidites may also occupy the Novgorod Zone in Russia. This zone is characterized by an irregular mosaic field of low magnetic anomalies, resembling that of the Bothnian area in the Fennoscandian Shield, and may thus be a representative of an ancient microcontinent [Peive et al., 1979].

The Tapa Zone is bordered by tectonic contacts from the Tallinn Zone in the west and Alutaguse Zone in the east, while the southern contact with the West-Estonian Zone is not so clearly defined (Fig. 1). The zone is characterised by slightly positive gravity and frizzy magnetic anomalies. The main rock types comprise a sequence of alternating Fe- and S-rich garnet- pyroxene-bearing quartzites, high-Al garnet-cordierite-sillimanite gneisses, and Ca-rich and Ca-poor pyroxene-, amphibole- and biotite gneisses. Mineralogical assemblages indicate amphibolite and granulite facies metamorphism. Migmatisation has resulted in potassium-feldspar- and plagioclase-rich leucosomes and granitic veins and bodies, and charnockitic veins in granulitic areas [Soesoo et al., 2006]. Generally, these rocks are mineralogically similar to those of the West-Estonian Zone (below). Also, the nature of their geophysical fields is similar to that in the West-Estonian Zone. 


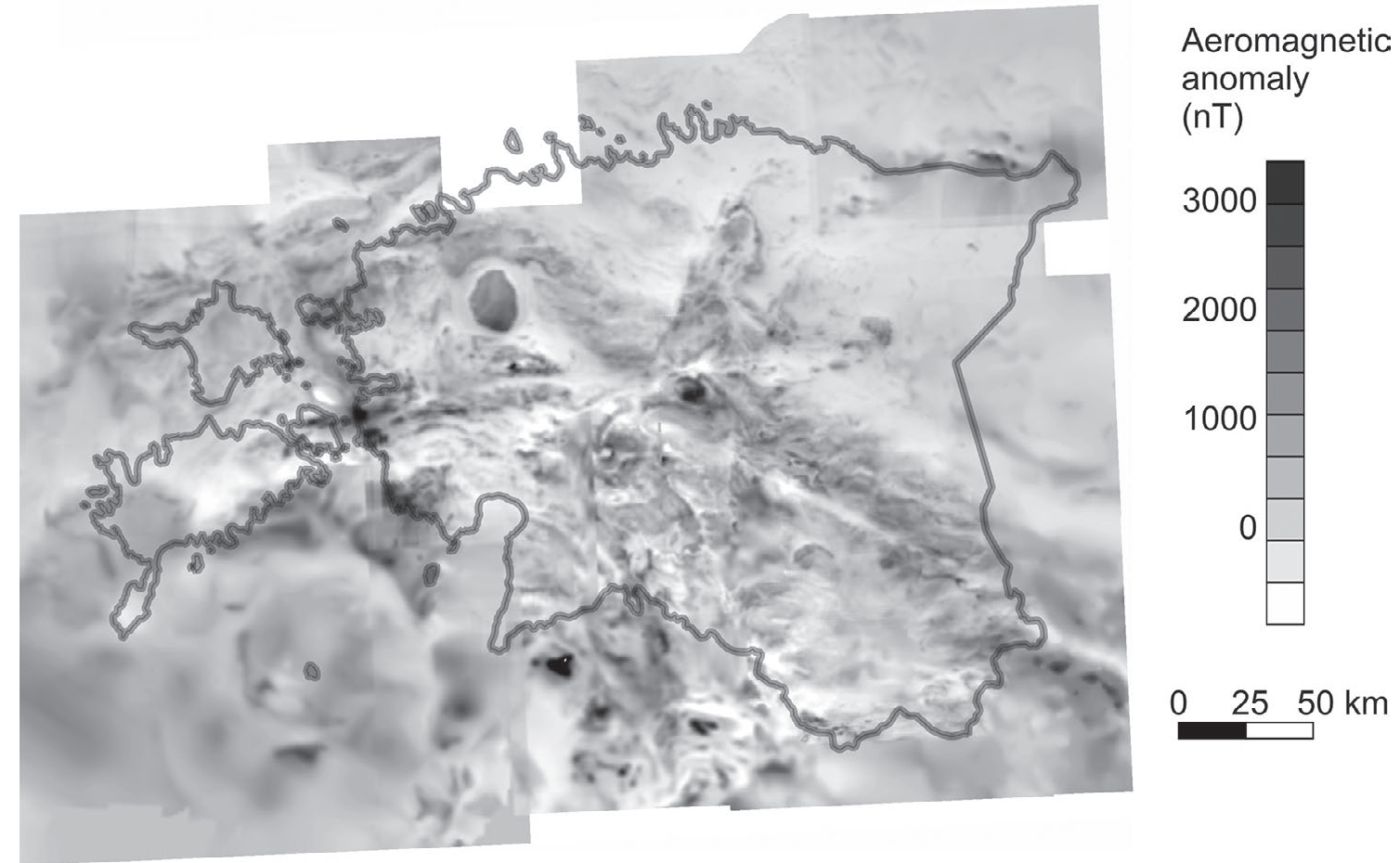

Fig. 3. Aeromagnetic map of Estonia. It is based on campaigns between 1987 and 1992 (unpublished reports in the Depository of Geological Reports by the Geological Survey of Estonia, see [All et al., 2004] for detail)

The narrow Jõhvi Zone is separated from the South-Estonian Zone by the Alutaguse Zone amphibolite grade gneisses. The Jõhvi Zone (Fig. 1) is characterised by extremely strong (up to $20000 \mathrm{nT}$ in the Jõhvi magnetic anomaly) $\mathrm{E}-\mathrm{W}$ trending magnetic anomalies and slight positive gravity anomalies. The complex consists of pyroxene gneisses, quartz-feldspar gneisses, biotite-plagioclase gneisses, amphibole gneisses, garnet-cordierite gneisses (Vaivara complex), and magnetite-rich quartzites and gneisses (Jõhvi magnetic anomaly). Migmatisation is widespread, resulting in the formation of plagioclase and potassium-feldspar porphyroblasts, occasionally leucosomes and small granitoid veins and bodies with charnockitic and enderbitic compositions. Generally, these rocks have formed under the conditions of granulite facies metamorphism. The rocks of this zone have a high ore potential.

The West-Estonian Zone is bounded by the NW- trending PPDZ and the E-W striking MiddleEstonian tectonic zone (MEFZ). The zone is dominated by metasedimentary rocks in the amphibolite to granulite facies, resembling somewhat the rocks in the southern part of the Bergslagen area in Sweden [Bogdanova et al., 2015]. The eastern part of the West-Estonian Zone is characterised by NW - SE striking strong linear magnetic anomalies, while the anomalies in the western part of the zone are mostly NE - SW or sub-N - S striking (Fig. 3). The free-air gravity anomaly is slightly positive (Fig. 2). The West-Estonian zone is also cut by several Proterozoic tectonic zones, the largest of which is the Hiiumaa - Espoo shear zone. The main rock types in the West-Estonian Zone are medium- to fine-grained amphibolites, biotite-plagioclase gneisses, and quartz-feldspar gneisses with minor pyroxene gneisses. The mineral assemblage of these rocks points to the hightemperature amphibolite facies and in a number of places to the granulite facies metamorphism [Puura et al., 1983, 2004]. The latter often contains migmatites or small granitic bodies of enderbitic composition, otherwise plagioclase - K-feldspar leucosomes and granites prevail.

The South-Estonian Zone (Fig. 1) was thought to be a part of the approximately $1000 \mathrm{ki}$ lometres long Belarus-Baltic Granulite Belt [Puura et al., 1983; Soesoo et al., 2004a]. which comprises predominantly meta-igneous rocks and minor meta-sedimentary rocks. The South-Estonian Zone is characterised by a band of intensive gravity and magnetic anomalies (Figs. 2 and 3 ) embracing the southern part of Estonia and northern Latvia. The magnetic field is strongly differentiated, the anomalies are generally linear and trend $\mathrm{E}-\mathrm{W}$ or $\mathrm{N}-\mathrm{S}$. The gravity field anomalies are coarsely mosaic. The boundary between the Southand West-Estonian zones generally follows the tectonic zones. The South-Estonian Zone contains 
both mafic and felsic granulitic components - amphibole-pyroxene and biotite-hypersthene gneisses, and quartz-feldspar gneisses. Both charnockitic and granitic migmatisation is observed. Some charnockites belong to a calc-alkaline I-type series, likely generated due to the melting of lower crust under granulite facies conditions along with the emplacement of some mafic dykes [Soesoo et al., 2006; Bogdanova et al., 2015]. This is somewhat younger than the $1.81 \mathrm{Ga}$ age of the granulite facies metamorphism in northern Latvia [Mansfeld, 2001]. In the southeast, the granulite continuation incorporates the large East Latvian block, which shows similarly a mosaic-type magnetic anomaly. The block is surrounded by linear anomaly belts and has previously been interpreted as an "Archaean" microcontinent [Bogatikov and Birkis, 1973] similar to the Novgorod domain [Bogdanova et al., 2015].

The evolution of the southern part of this zone commenced with metamorphism under amphibolite facies conditions, followed by peak (granulite facies) metamorphism under pressure and temperature conditions ranging between $740-760^{\circ} \mathrm{C}$ at $7-8 \mathrm{kbar}$ and $770-850^{\circ} \mathrm{C}$ at $5.5-7 \mathrm{kbar}$ [Taran and Bogdanova, 2001]. According to Bogdanova et al. [2015], the South-Estonian Zone is no longer the northern extension of the Belarus-Baltic granulite belt, but is truncated by the latter, which is now considered to associate with Sarmatia rather than Fennoscandia.

In conclusion, the rocks with granulite metamorphic assemblages are found in a number of zones within the Estonian basement. In the South-Estonian and Jõhvi Zones, the granulite facies mineral assemblages are still preserved, while in the Tapa and West-Estonian Zones the rocks were mostly retrogressed under amphibolite facies conditions [Puura et al., 1983, 2004; Fig. 1].

\section{Metamorphism of the Estonian Precambrian basement}

Metamorphic rocks predominate in the Precambrian basement of Estonia. Earlier mapping of the buried basement rocks was performed by combining regional potential geophysical field data and drill core studies of about 490 drill holes. These metamorphic belts belong to the uniform Svecofennian crustal domain spreading over 1 million $\mathrm{km}^{2}$ in the western corner of the East European Craton [Puura et al., 2004]. Within this domain, metamorphic zones from low- to high-grade metamorphism have been observed. Within the Estonian basement, the rocks of high-grade amphibolite to granulite facies dominate. Detailed studies, however, revealed that spatial variations in me- tamorphic grade are widespread. Metamorphic gradients related to fault zones, roughly circular or belt-form areas of increasing metamorphic grade (metamorphic domes) feature the general highgrade metamorphic field.

The structural-geological zones distinguished in the basement of Estonia substantially vary also in metamorphic lithologies. Previous studies have revealed that in primary supracrustal suites, a large variety of mafic, intermediate and acidic volcanic rocks, as well as clastic sediments from clays to sands, occasionally with carbonate admixture, constitute the basement rock units [Koppelmaa et al., 1978; Puura et al., 1983; Klein, 1986]. Some information on the protoliths of metamorphic rocks has been obtained by studying the typologies of zircons [Konsa, 1986; Konsa and Puura, 1999].

The average mineral contents of different supracrustal rocks in these geological zones of the basement were reported by Puura et al. [2004]. For example, in Tallinn and Alutaguse zones, Al-rich garnet-, cordierite- and sillimanite-bearing-gneisses and biotite gneisses account for 25.4 vol\% and 90.5 vol\%, respectively, while biotite-plagioclase and K-feldspar-bearing gneisses constitute $24.4 \%$ and $1 \%$, respectively. Biotite-plagioclase, hornblende-plagioclase, pyroxene-plagioclase gneisses and amphibolites constitute 50.2 vol\% and $6.1 \mathrm{vol} \%$, respectively [Klein, 1986].

In the South- and West-Estonian zones, pyroxene- or hornblende-bearing mafic metavolcanic rocks dominate, respectively, whereas metapelites and granitic gneisses are rare. Pre-metamorphic textural features in high-grade metamorphic rocks have been obliterated. However, occasionally graded bedding has been observed in metapelites. Sedimentary protoliths of metapelites in the Tallinn and Alutaguse zones are supported by findings of zoned zircons, whose rounded cores suggest their detrital origin [Konsa and Puura, 1999]. The distinction between sedimentary or volcanic origin of metamorphic suites, especially in cases of Ca-rich composition resembling mafic volcanics, was drawnusing the bulk chemical composition and spatial relationships of metamorphic rock suites in metamorphic sequences [Puura et al., 1983].

Based on the mineral parageneses and chemical compositions of minerals (historical wet chemical analysis of garnet, biotite and amphibole fractions [Puura et al., 1983; Klein, 1986] and microprobe analyses [Kikas, 2001], the peak metamorphic conditions in the main structural zones of the Estonian basement were estimated. The data revealed that high temperature and moderate pressure amphibolite facies conditions do- 
minated in the Tallinn and Alutaguse zones. Geothermobarometry of biotite+garnet+/-sillimanite assemblage and cordierite suggests peak metamorphic conditions at $600-700^{\circ} \mathrm{C}$ and $3-5 \mathrm{kbar}$ [Klein, 1986; Koistinen, 1996]. In South Estonia, the mineral parageneses of intermediate and mafic metavolcanics and Al-rich gneisses correspond to granulite facies. Widespread garnet and cordierite in these rocks formed by the breakdown of biotite and sillimanite, which indicates prograde metamorphism. However, in many places retrograde assemblages formed in the conditions of amphibolite facies metamorphism. Hölttä and Klein [1991] studied drill cores in the granulite rocks of South Estonia and gave pressure estimates close to 4-6 kbar and formation temperature at around $700-800^{\circ} \mathrm{C}$.

Kikas [2001] performed detailed studies of rock-forming mineral assemblages from rocks of the Kõnnu drill core (granulite facies, South-Estonian Zone) and the Valgu drill core (amphibolite facies, West-Estonian Zone). These drill cores were located close to the MEFZ (Fig. 1), virtually on its opposite sides. Traces of partial melting imply that melting was the prominent mechanism for dehydration of rocks in the Kõnnu and Valgu drill cores. In the granulitic rock, the occurrence of orthopyroxene and hercynite, and a specific chemical composition of high-grade phases, such as high titanium content in biotite and high alumina content in orthopyroxene, are in accordance with geothermobarometric estimates, which suggests a peak temperature of formation over $800^{\circ} \mathrm{C}$ and pressure of 5-6 kbar. In amphibolitic rock, geothermobarometric estimates suggest peak conditions at the upper amphibolite facies - temperature $\sim 700^{\circ} \mathrm{C}$, and pressure $\sim 4.5-5.5 \mathrm{kbar}$. These estimates show a difference in the metamorphic stages and history between the West-Estonian and the South-Estonian zones leading to the general conclusion that the South-Estonian Zone shows a deeper erosion level.

\section{Precambrian unmetamorphosed igneous rocks in the Estonian basement}

Within the Estonian basement, post-orogenic (later than Svecofennian collisional processes) and anorogenic (independent from Svecofennian orogenic framework) magmatic rocks were recognized by drilling and from gravity and magnetic investigations back in the mid-20 th century [Tikhomirov, 1965; Bogatikov and Birkis, 1973; Kuuspalu, 1975; Puura et al., 1976, 1983; Velikoslavinsky et al., 1978; Kirs and Petersell, 1994; Rämö et al., 1996]. This rock group has been relatively well studied. Generally, the igneous rocks are widely distributed in the Proterozoic basement of Estonia, however, they do not form large plutons. Granitic rocks are widespread and present in about 400 drill cores. The group of granitic igneous rocks also contains effusive varieties, which are found in more than 80 drill cores. Intermediate to basic and ultrabasic rocks are much less common - they are present in about 80 drill cores.

In the historical research, mostly based on drill core observations, the granitoids are traditionally divided into syn- and late-orogenic granites [Niin, 1997]. The synorogenic granitoids were described from about 50 drill cores, where hypersthene-bearing charnockites and enderbites predominate. Geochemically, synorogenic granites show type I characteristics and their genesis is related to granulitic metamorphism [Niin, 1997], although some authors have investigated them together with late-orogenic migmatite granites [Puura et al., 1997]. These granites are widely spread in the South-Estonian and Jõhvi granulitic zones, where they form veins, small lenses and bodies. The other group of synorogenic granitoids is represented by granodiorites and occasionally quartz diorites. These rocks show gneissic structure and occur mainly as small plutons. They are usually found in the Tallinn and Jõhvi zones.

The Estonian late-orogenic granitoids occur in more than 300 drill cores and are known in all geological zones, although less often in the South-Estonian and Jõhvi granulitic zones. In the mineral and chemical composition granites, granodiorites dominate, tonalites and adamellites occur less often, while quartz-diorites, quartz-monzonites and quartz syenites are recorded only in a few drill cores. Usually, they form veins, but migmatitic rock bodies are also frequent. These granites are mainly massive, pegmatoid texture is common, gneissic varieties are rare, while porphyraceous texture occurs very seldom. Most of them probably have metasomatic or anatectic origin [Niin, 1997]. Most of the quartz-feldspar- and granitic-gneisses are considered to belong to acid metavolcanites [Niin, 1997] such as dacites, rhyolites, porphyries, etc. Acid metavolcanic rocks are the most common in the West-Estonian and Tallinn zones.

Intermediate rocks were described from about 40 drill cores, half of them from the West- Estonian Zone. The main types of intermediate igneous rocks are gabbroic diorites (meta? - gabbro-diorites) and diorites. The mafic, basic in composition, igneous rocks are found in more than 70 drill cores; again, half of them in the West-Estonian Zone [Niin, 2002]. However, most of them show metamorphism. The share of ultrabasic igneous rocks in the crystalline basement of Estonia is 
small (four drill cores) and they have commonly been considerably altered during metamorphism and secondary processes [Niin, 2002].

Anorogenic rocks belong to the Fennoscandian Paleo - Mesoproterozoic Rapakivi Province [Koistinen, 1994; Puura and Floden, 1999] and include the huge composite Riga batholith, as well as at least five minor stock-like porphyritic K-granite plutons - Naissaare, Märjamaa (with its Kloostri satellite), Neeme, Ereda and a quartz-monzodioritic Abja stock in SW Estonia [Kuuspalu, 1975; Soesoo and Niin, 1992; Soesoo, 1993]. All the rock bodies, except for the Abja pluton, are situated in the northern part of Estonia (Fig. 1). Usually, these plutons are seen in strong but short-wavelength positive magnetic anomalies.

The anorogenic Riga pluton, which forms the southern part of Riga-Åland Rapakivi Subprovince [Puura and Floden, 1999], contains both mafic and silicic rocks, which are petrographically and geochemically analogous to the typical members of the Fennoscandian Rapakivi-anorthositic suite. As in the case of other large rapakivi granite batholiths, a considerable effect of crustal thinning - at a scale of $10 \mathrm{~km}$ - has occurred in the Riga batholith area in connection with its formation [Puura and Floden, 1999, 2000]. Geophysical effects of the Riga pluton are expressed in low-gradient negative to near-zero gravity and magnetic fields in the Gulf of Riga, SW Saaremaa and the Courland Peninsula in Latvia (Figs. 1-3).

These small Rapakivi-like porphyritic potassium-granite intrusions in the Estonian mainland show up as small gravity and magnetic minima (Ereda, Neeme, Naissaare, Taebla, and Kloostri stocks), and comprise pink, medium- to coarsegrained, microcline-megacrystic, partly trachytoid biotite (in Märjamaa and Naissaare also biotite-hornblende) syeno- and monzogranitic rock, locally cut by aplitic and microsyenitic dykes [Kuuspalu, 1975; Kirs, 1986; Soesoo and Niin, 1992]. As an exception, Märjamaa pluton is more differentiated with an anomalously high-magnetic central part containing hybrid granodiorite with hastingsitic hornblende as the main mafic mineral. The major and trace element contents of these porphyritic potassium-granites are similar to or overlapping with those of typical Finnish rapakivi and comparable with the less differentiated granitic phases from the Wiborg and Laitila plutons [Kuuspalu, 1975; Soesoo and Niin, 1992; Kirs et al., 2004]. Märjamaa pluton is accompanied by a remarkable ellipsoidal magnetic high and an annular low (Fig. 3). A central weakly positive local gravity anomaly with a negative ring (Fig. 2) also associates with Märjamaa.
The Abja quartz- monzodioritic pluton in SW Estonia is strongly magnetic and consists of a dark gray, massive, medium-grained, partly weakly gneissose rock with abundant accessory apatite and titanomagnetite. It is intersected by veins of fine to medium-grained slightly porphyritic plagioclase-microcline granite. The Sigula intrusion in North Estonia consists of medium grained gabbro-monzonitic rock with ophitic texture and of massive structure. This rock is very rich in titanomagnetite (up to $10 \%$ ), apatite (2-4\%), and titanite. The other postorogenic body - Utria stock in NE Estonia, consists of medium-grained fresh, non-amphibolised gabbro-diorite with high titanite $(3-5 \%)$ content.

\section{Geochronology of the Estonian basement}

The first attempts to determine the isotopic age of the Estonian basement rocks were carried out in the 1970's [Puura, 1974]. Three groups of isotope systematics (K-Ar, $\mathrm{Sr}-\mathrm{Rb}$ and $\mathrm{U}-\mathrm{Pb}$ ) were used in geochronological studies. In the early 1990's, Sm-Nd analyses on the granulitic gneisses from the South Estonian drill cores were carried out [Huhma et al., 1991b; Puura and Huhma, 1993]. These results along with new U-Pb zircon age determinations [Petersell, 1991, 1993; Petersell and Levchenkov, 1994; Rämö et al., 1996] eventually refuted the decades-long opinion of an Achaean age of South Estonian granulites and suggested a Palaeoproterozoic age for the granulite protolith.

The U-Pb zircon age of metavolcanic rocks of amphibolitic facies from northern Estonia (for example drill core F-164) yielded a range of ages within the 5 zircon fractions analysed - from 1889 $\mathrm{Ma}$ to $1844 \mathrm{Ma}$, while the isochrone age was $1918 \pm 10 \mathrm{Ma}$ [Petersell and Levchenkov, 1994] Thirteen samples of granulitic metavolcanic rocks of the South-Estonian Zone yielded $\mathrm{U}-\mathrm{Pb}$ zircon ages between 1833-1802 Ma and isochrone age groups of $1832 \pm 22$ and $1827 \pm 7$ Ma [Petersell and Levchenkov, 1994]. Al-rich gneisses of metasedimentary origin from the same rock complex (drill core F-502) showed a range of TIMS multigrain U-Pb zircon ages between 1930 and 1841 Ma. Preliminary studies of zircons (drill core F-502) by the laser ablation ICP-MS technique also showed a range of ages - from 1900 to 1736 Ma [Soesoo et al., 2004a] (Table). The relatively large range of ages within the metasedimentary component probably points to mixed populations of zircons, where some older, but radiogenically similar sedimentary material may be present. $\mathrm{U}-\mathrm{Pb}$ monazite dating of an orthopyroxene-garnet gneiss form the South-Estonian Zone yielded an age of $1778 \pm 2 \mathrm{Ma}$ [Puura et al., 2004]. 
Rock types, general geochronology, possible correlations and tectonic settings of the rock complexes of the Estonian basement [modified after: Kirs et al., 2009]

\begin{tabular}{|c|c|c|c|c|c|}
\hline $\begin{array}{l}\frac{\pi}{0} \\
\frac{\mathbb{0}}{8} \\
\frac{0}{0} \\
0 \\
0\end{array}$ & 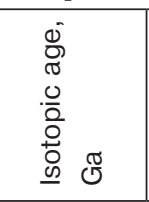 & Rock types & Geographical position & Possible correlations & Tectonic settings \\
\hline & $<1.40$ & \multicolumn{4}{|c|}{ Late Calymmian erosion and intraplate processes } \\
\hline \multirow{3}{*}{ 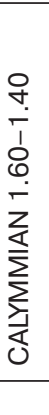 } & \multicolumn{5}{|c|}{ Some uplift, extensional tectonics } \\
\hline & $1.59-1.54$ & $\begin{array}{l}\text { quartz-porphyries, plagi- } \\
\text { clase-porphyrites }\end{array}$ & $\begin{array}{l}\text { Rapakivi plutons of } \\
\text { Riga-Aland subprovince: } \\
\text { Riga pluton }\end{array}$ & $\begin{array}{l}\text { SW Finland and central } \\
\text { Sweden }\end{array}$ & $\begin{array}{l}\text { Uplift } \\
\text { Extension? }\end{array}$ \\
\hline & 1.60 & & & & \\
\hline \multirow{3}{*}{ 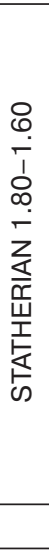 } & $1.67-1.62$ & $\begin{array}{l}\text { quartz-porphyries, plagi- } \\
\text { clase-porphyrites, }\end{array}$ & $\begin{array}{l}\text { Rapakivi plutons } \\
\text { of Wiborg subprovince: } \\
\text { Märjamaa, Neeme, } \\
\text { Ereda, Naissaare, Taebla } \\
\text { plutons }\end{array}$ & $\begin{array}{l}\text { Suursaari, } \\
\text { Gulf of Finland }\end{array}$ & $\begin{array}{l}\text { Block tectonics, exten- } \\
\text { sion? volcanism }\end{array}$ \\
\hline & & shoshonites & shoshonitic pluton: Abja & $\begin{array}{l}\text { S and SE Finland, } \\
\text { Ladoga area }\end{array}$ & $\begin{array}{l}\text { Uplift, } \\
\text { extension? }\end{array}$ \\
\hline & 1.80 & \multicolumn{4}{|c|}{ Amalgamation of Fennoscandian, Sarmatian etc. megablocks, Formation of Columbian Supercontinent } \\
\hline \multirow{4}{*}{ 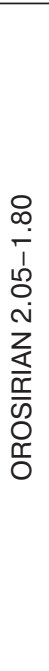 } & 1.83 & post-orogenic shoshonites & $\begin{array}{l}\text { shoshonitic plutons: } \\
\text { Virtsu, Taadikvere, Muhu }\end{array}$ & $\begin{array}{l}\text { S and SE Finland, } \\
\text { Ladoga area }\end{array}$ & $\begin{array}{l}\text { Uplift, erosion, exten- } \\
\text { sional collapse }\end{array}$ \\
\hline & $1.84-1.80$ & $\begin{array}{l}\text { granites, } \\
\text { microcline granites, } \\
\text { charnockites }\end{array}$ & $\mathrm{N}$ and NW Estonia & $\begin{array}{l}\text { SE Sweden, Central } \\
\text { and S Baltic area, } \\
\text { S and SE Finland }\end{array}$ & $\begin{array}{l}\text { Processes at active } \\
\text { margins, island arc \& } \\
\text { back-arc basins }\end{array}$ \\
\hline & $1.93-1.88$ & $\begin{array}{l}\text { granites, } \\
\text { microcline granites, } \\
\text { charnockites }\end{array}$ & $\mathrm{N}$ and NW Estonia & Finland, NW Russia & $\begin{array}{l}\text { Processes at active } \\
\text { margins and back-arc } \\
\text { basins }\end{array}$ \\
\hline & $>2.05$ & \multicolumn{4}{|c|}{ Opening and spreading of the Svecofennian ocean } \\
\hline
\end{tabular}

These ages are significantly younger than the ages of other mafic meta-igneous rocks from northern Estonia or granulite facies rocks in Finland [Huhma et al., 1991a].

Metavolcanites from the four SW Estonian drill cores demonstrated a Sm-Nd model age $\left(\mathrm{T}_{\mathrm{DM}}\right)$ of 2.08 to $2.18 \mathrm{Ga}$, while $\varepsilon_{\mathrm{Nd}} \mathrm{T}$ varied from +0.2 to +2.0 [Huhma et al., 1991b]. Partial melting of granulitic rocks of the South-Estonian and Tapa zones has been studied by Soesoo et al. [2006]. Zircons extracted from the tonalite of the Tapa Zone yielded $1824 \pm 26 \mathrm{Ma}$, while tonalite from the South-Estonian Zone yielded the age of $1788 \pm 16 \mathrm{Ma}$. Charnockite from the Tapa Zone yielded $1761 \pm 11 \mathrm{Ma}$ [Soesoo et al., 2006]. These $\mathrm{U}-\mathrm{Pb}$ crystallisation ages span over ca. $80 \mathrm{Ma}$, 
suggesting a prolonged high-grade metamorphism or several separate metamorphic/melting events. An attempt was made to compare zircon $\mathrm{U}-\mathrm{Pb}$ and whole-rock Nd ages (Fig. 4). The Nd model age of partial melting of granulite facies mafic gneiss shows an intercept age of $1760 \mathrm{Ma}$, which is in good concordance with the $\mathrm{U}-\mathrm{Pb}$ zircon age from the same charnockite sample $-1761 \pm 11 \mathrm{Ma}$ (Fig. 4).

Some new geochronological data just became available from the Jõhvi Zone. Zircons from the gneisses, which are associated with a large body of magnetite quartzites, represent three groups of ages. A majority of the zircons show $1826 \pm 10 \mathrm{Ma}$, the youngest population is at $1789 \pm 19 \mathrm{Ma}$, while the third population gives the isochrone age of $1874 \pm 18 \mathrm{Ma}$ (RITA project, unpublished data). These gneisses are migmatised and the magnetite-quartzites are cut by microcline granite veins. The granitic vein yielded an $\mathrm{U}-\mathrm{Pb}$ zircon age of $1800 \mathrm{Ma}$, which may be the age of migmatization (A. Soesoo, unpublished data). The latter age is similar to the ages of lateand/or post-orogenic granites in southern Finland [Nironen, 2005; Kurhila et al., 2011].

The knowledge about the age of metamorphism is based on a few studies of $\mathrm{U}-\mathrm{Pb}$ analysis of zircon and monazite and some other isotope studies of rocks and minerals [Puura et al., 2004; Soesoo et al., 2006]. The granulite metamorphism age is difficult to estimate directly, however monazite from an Estonian orthopyrexene-garnet gneiss (drill core F-300, South-Estonian Zone) yielded an age of $1778 \pm 2 \mathrm{Ma}$ [Puura et al., 2004]). This age is similar to that of gabbro-noritic dyke which cuts the same granulites $-1.774 \pm 20 \mathrm{Ga}$ (A. Soesoo,

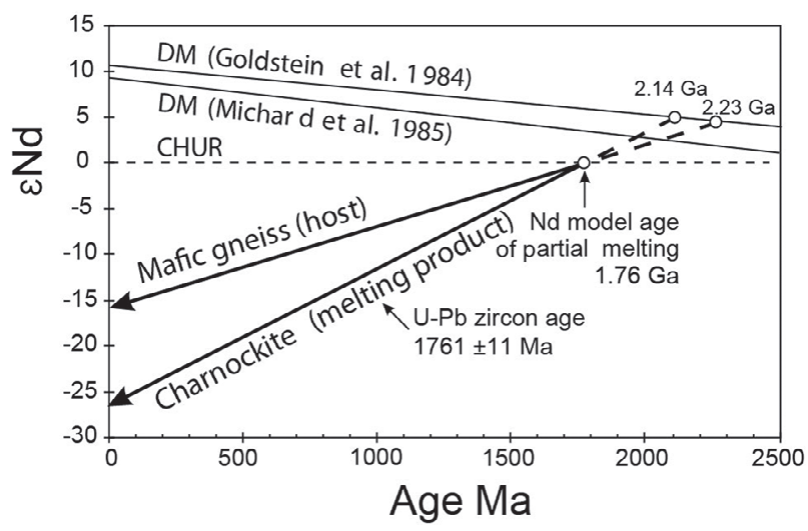

Fig. 4. Evolution of $\mathrm{Nd}$ isotopic composition in the mafic gneiss and its partial melting product - charnockite - relative to the evolution of the Chondritic Uniform Reservoir (CHUR [Jacobsen and Wasserburg, 1980]) and depleted mantle (DM [Goldstein et al., 1984; Michard et al., 1985]). Note that the U-Pb zircon age of the charnockite is the same $-1761 \pm 11 \mathrm{Ma}$ [modified from: Soesoo et al., 2006] unpublished data). The Sm-Nd age of garnets from this gneiss yielded $1728 \pm 24 \mathrm{Ma}$, which can be interpreted as the age when the rocks cooled down to the closure temperature of garnets, i. e. ca. $650-700^{\circ} \mathrm{C}$. The associated tonalite from the South-Estonian Zone gave comparable U-Pb zircon ages - $1788 \pm 16 \mathrm{Ma}$ [Soesoo et al., 2006], similar to whole-rock Sm-Nd and $\mathrm{U}-\mathrm{Pb}$ zircon ages of partial melting within the Tapa Zone (1760 Ma [Soesoo et al., 2006]; Fig. 4). Supposedly, the formation of tonalites and charnockites (likely conditions: $850^{\circ} \mathrm{C}$ and 6 kbar) in Estonian granulites occurred at ca. 1788-1778 Ma. Then, the rocks cooled down, passing through the garnet closure temperature of ca. $650-700^{\circ} \mathrm{C}$ at $1728 \pm 24$ Ma. Thus, the age of metamorphism of the Estonian granulites is lower than the metamorphic ages known from southern Finland, but it is similar to the age of metamorphism reported from the Belarus-Baltic Granulite Belt in Latvia.

The U-Pb and Sm-Nd isotopic studies on the Svecofennian granulite areas in Finland clearly show that there are two distinct granulite facies pulses, at ca. $1.88 \mathrm{Ga}$ and at ca. 1.80-1.83 $\mathrm{Ga}$. Migmatites from the Turku area have yielded $\mathrm{U}-\mathrm{Pb}$ zircon ages of ca. 1.82 Ga [Väisänen et al., 2002]. The West Uusimaa migmatites have yielded $\mathrm{U}-\mathrm{Pb}$ ages on monazites from $1816 \pm 2 \mathrm{Ma}$ to $1832 \pm 2 \mathrm{Ma}$, whereas $\mathrm{Sm}-\mathrm{Nd}$ on garnet gives an average age of $1803 \pm 6$ Ma [Väisänen et al., 2002].

The post-orogenic magmatism is represented by small monzonite-type mafic to felsic plutons of shoshonitic geochemical affinity, originating from enriched lithospheric mantle, and having been emplaced within the Estonian crust at $1830 ?$ - 1630 Ma [Soesoo and Hade, 2012]. Partly gneissic rocks of the Muhu quartz-monzonite and Taadikvere granodiorite plutons show an $\mathrm{U}-\mathrm{Pb}$ isotope age of about $1830 \mathrm{Ma}$ (V. Petersell, unpublished data), which is in a problematic position to metamorphism (Table). The shoshonitic Virtsu pluton yields, however, an U-Pb age of about 1610 Ma [Soesoo and Hade, 2012]. The quartz-monzonite of the Abja pluton shows a similar zircon $\mathrm{U}-\mathrm{Pb}$ age - $1638 \mathrm{Ma}$. It is interesting to note that the granitic rocks emplaced into the Abja mafic pluton show zircon fractions with ages from 1610 to $1515 \mathrm{Ma}$ with an isochrone age of $1622 \pm 7 \mathrm{Ma}$ [Kirs and Petersell, 1994] (Table).

In spite of age differences between the Muhu (1803 Ma), Abja and Virtsu (1606 and $1638 \mathrm{Ma}$, respectively) shoshonites, they all show similar chemical affinities. It is also interesting that some of the Virtsu and Muhu rock types (high-K varieties) are chemically similar to the Finnish rapakivi granites, while others are similar to shoshonites. 
The Fennoscandian anorogenic anorthosite-rapakivi plutons developed in the time span of 1.67-1.45 Ga within the Svecofennian juvenile crust. Several igneous Rapakivi subprovinces consisting of mafic to felsic intrusive rocks and volcanic facies have been distinguished in the region. They can be divided into two large units: the Wiborg Subprovince of 1670-1620 Ma and the CaIymmian Riga-Åland Subprovince of 1590-1540 $\mathrm{Ma}$ age. As Estonia is located in the central part of the Fennoscandian rapakivi province, granitoids temporally similar to both Rapakivi subprovinces are found here. Granodiorite of the Märjamaa pluton yields an U-Pb zircon age of 1650-1630 Ma [Rämö et al., 1996; A. Soesoo, unpublished data]. The Neeme granitoids yield an U-Pb zircon age of $1634 \mathrm{Ma}$ and the Taebla rocks $1648 \mathrm{Ma}$, whereas the Ereda rocks show two age groups of 1642 and $1627 \mathrm{Ma}$ (A. Soesoo, unpublished data).

The Calymmian granitoids in Estonia are so far known only from the Riga-Åland rapakivi Subprovince, on the islands of Saaremaa and Ruhnu. The basement beneath the Gulf of Riga as well as on Ruhnu Island and western Saaremaa Island is represented by the northern portion of the Riga batholith. Zircons from the Riga batholith yield ages of 1576-1584 Ma [Rämö et al., 1996]. Zircons from a subvolcanic biotite granite porphyry unit in Ruhnu Island (Riga batholith) yield an age of $1595 \mathrm{Ma}$ [Soesoo and Hade, 2012] (Table).
Relying upon the available data it can be concluded that the Svecofennian orogenic structures in the Estonian basement formed during Paleo-Proterozoic time, 1.8-1.9 Ga and compose magmatic, volcanic and sedimentary components across both major structural zones. The granulite metamorphism and possibly the associated mafic magmatism (including crustal melting events) postdate these ages. It is not clear yet whether the age differences between granulitic (SW Estonia) and amphibolitic facies (NE Estonia) volcanic rocks hint at differences in the geotectonic position of these rocks or are explained by different exhumation sections, or both.

\section{Metallogenesis of the Estonian Precambrian basement}

Along with the fundamental studies describing the evolution of the crystalline basement, the signs of metallogeny have always been taken into account as potential economic resources. Moreover, during the crystalline basement mapping, a fair amount of the deep drill holes were drilled for exploration purposes to determine the geological features that are causing magnetic and gravimetric anomalies. As a result, several geochemical anomalies of high metal concentrations have been detected (Fig. 5).

Previous geochemical studies [Kivisilla, 1987] show that north-eastern Estonia together with

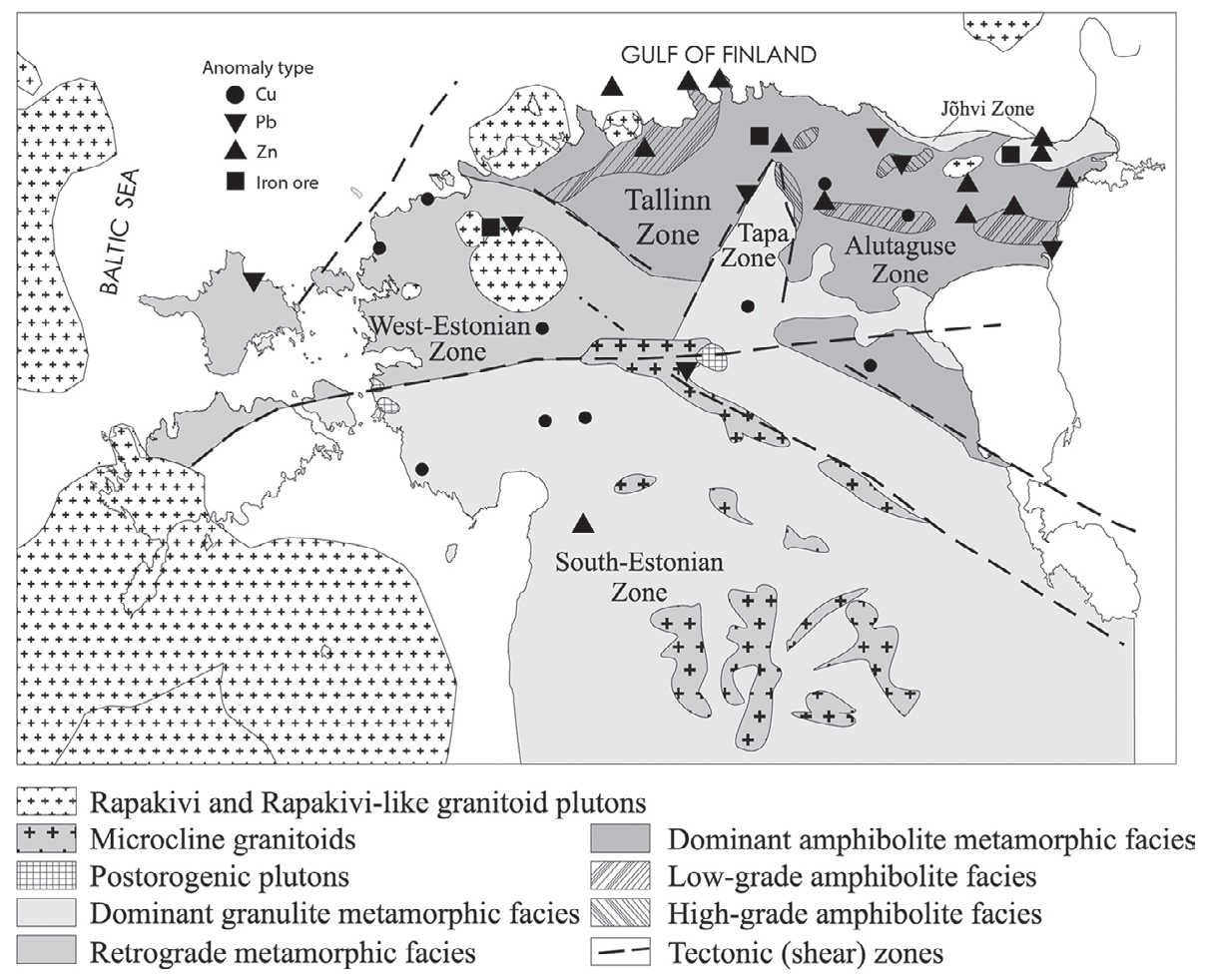

Fig. 5. Geochemical anomalies in the Estonian Precambrian basement. Anomaly symbol represents the most prominent metal of the mineralization 
the Tallinn Zone differs from the crystalline basement in their higher concentration of chalcophile and siderophile elements, making it relevant from metallogeny and therefore the ore potential points of view.

Mn-rich magnetite quartzites are found in the Jõhvi Zone of the Vaivara rock complex, forming the Jõhvi iron ore deposit, and in Sakusaare, where comparable mineralization can be seen in the Jägala rock complex of the Tallinn zone [Luha, 1946; Erisalu and Arvisto, 1969; Petersell, 1976; Petersell et al., 1985].

First studies on Jõhvi magnetite quartzites were carried out in 1918-1939 [Luha, 1946]. As the magnetic anomaly is complex and produced by subvertical ore bodies, only 5 out of 17 holes drilled in the area of the anomaly intersected Fe-quartzites [Erisalu and Arvisto, 1969]. Fe-mineralization spreads in garnet-cordierite, amphibole- and pyroxene gneisses. Banded magnetite with occasional braunite inclusions and quartz interlayers is often seen together with pyrrhotite and pyrite [Puura and Kuuspalu, 1966; Petersell et al., 1985]. In rare occasions, magnetite is replaced by hematite and in some cases up to $10 \%$ of the magnetite is replaced by goethite. Magnetite quartzites contain up to $45 \%$ total iron per 1 metre interval. The total depth of the ore body exceeds $721 \mathrm{~m}$, although the true thickness has not yet been determined.

Various concepts of ore genesis have been proposed for Jõhvi Fe-quartzites. A. Linari [1940] suggests the ore is skarn-like. Also, ore genesis through metasomatism has been proposed [Vaganova and Kadõrova, 1948], where Fe-quartzite was formed from mafic rocks during regional metamorphism while in contact with granites. Tihomirov [1966] has described rocks as alternating layers of skarn, cummingtonite, biotite-sillimanite and other hornfels that are cut by granite veins. However, the most widely recognized is the concept of metamorphic rocks of volcanogenic-sedimentary origin [Puura and Kuuspalu, 1966; Erisalu and Arvisto, 1969].

Additionally, a slight amount of fine-grained magnetite along with hematite, pyrrhotite and pyrite may occur in small-grained cordierite-sillimanite-biotite metasedimentary alumo-gneisses throughout Estonia. In gabbroic intrusions, ilmenite-magnetite and magnetite-apatite mineralization has also been noted [Petersell et al., 1991].

Along with various iron-related minerals, significant anomalies of sidero-chalcophile sulphide-graphite-bearing mica gneisses occur in the Tallinn and Alutaguse zones [Vaher et al., 1962]. Areas of prominent mineralization produce distinct magnetic anomalies, e. g. Haljala, Assamalla, Uljaste, where the total concentration of $\mathrm{Cu}$, $\mathrm{Pb}$ and $\mathrm{Zn}$ can be as high as $5.6 \%$. Graphite con- centration in graphite gneisses is highly variable, reaching up to $10-15 \%$. Moreover, in the Palamuse drill core, a $1.6 \mathrm{~m}$ thick fine-grained layer contains up to $36 \%$ of graphite. Together with iron sulphides, polymetallic mineralization is observable. Pyrrhotite is the most common sulphide mineral, spreading dispersedly in up to a few $\mathrm{cm}$-thick layers in the gneissic texture, and often replaced by pyrite. Iron sulphides have later been cut by sphalerite, chalcopyrite and galena [Vaher et al., 1964; Puura et al., 1967, 1983; Petersell, 1976; Petersell et al., 1985, 1991]. The second stage is more common for brecciated rocks with apparent cracks and caverns [Vaher et al., 1964]. Graphite gneiss formations are ultimately metamorphosed in the conditions of amphibolite facies metamorphism.

Tõnis Oja is acknowledged for providing gravity data.

We acknowledge the funding from the RITA programme by the European Regional Development Fund, the work programme "Metallogenesis of the Jõhvi area".

\section{References}

All T., Puura V., VaherR. Orogenic structures of the Precambrian basement in Estonia as revealed from the integrated modelling of the crust. Proceed. Estonian Acad. Sci., Geol. 2004. Vol. 53, no. 3. P. 165-189.

Ankudinov S., Sadov A., Brio H. Crustal structure of Baltic countries on the basis of deep seismic sounding data. Proceed. Estonian Acad. Sci., Geol. 1994. Vol. 43. P. 129-136. (In Russian with English summary)

Baker J. A., Hellingwerf R. H., Oen I. S. Structure, stratigraphy and ore-forming processes in Bergslagen: implications for the development of the Svecofennian of the Baltic Shield. Geologie en Mijnbouw. 1988 Vol. 67. P. 121-138.

Bogatikov O. A., Birkis A.P. Precambrian magmatism of western Latvia. Moscow: Nauka, 1973. P. 1-138. (In Russian)

Bogdanova S., Gorbachev R., Skridlaite G., Soesoo A., Taran L., Kurlovich D. Trans-Baltic Palaeoproterozoic correlations towards the reconstruction of supercontinent Columbia/Nuna. Precambrian Res. 2015. Vol. 259. P. 5-33.

Bondarenko L., Dagelaiskii V. Geology and metamorphism of the central part of the Kola Peninsula. Leningrad: Nauka, 1968. P. 1-167. (In Russian)

Dmitrieva M., Plado J., Oja T. The Luusika potential field anomaly, eastern Estonia: modelling results. Est. J. Earth Sci. 2018. Vol. 67, no. 4. P. 228-237.

Erisalu E., Arvisto E. Report of the basement studies on Jõhvi magnetic anomaly and nearby. Tallinn: Geol. Survey of Estonia. EGF 3032, 1969. P. 1-257. (In Russian)

Fotiadi E. E. Geology of the Russian Platform according to regional geophysical survey and deep drilling data. Moscow: Gosgeoltechizdat, 1958. P. 1-244. (In Russian) 
Gaal G. Tectonic styles of Early Proterozoic ore deposition in the Fennoscandian Shield. Precambrian Res. 1990. Vol. 46. P. 83-114.

Gorbatschev R., GaalG. The Precambrian history of the Baltic Shield. Proterozoic lithospheric evolution. Washington: American Geophysical Union, 1987. P. $149-159$

Grigelis A., Puura V. (eds). Geological map of the crystalline basement of the Soviet Baltic Republics. Scale 1:500 000. 1978.

Hietanen A. Generation of potassium-poor magmas in the northern Sierra Nevada and the Svecofennian in Finland. J. Res. U. S. Geol. Surv. 1975. Vol. 3. P. 631-645.

Hölttä P., Klein V. PT-development of granulite facies rocks in southern Estonia. Geol. Survey of Finland. Current research 1989-1990, Special Paper. 1991. Vol. 12. P. 37-47.

Huhma H., Claesson S., KinnyP. D., Williams I. S. The growth of Early Proterozoic crust: new evidence from Svecofennian detrital zircons. Terra Nova. 1991a. Vol. 3. P. $175-178$.

Huhma H., Puura V., Klein V., Mänttäri I. Nd-isotopic evidence for Paleoproterozoic crust in Estonia. Geol. Survey of Finland. Special Paper. 1991b. Vol. 12. P. 67-68.

Kähkönen $Y$. Svecofennian supracrustal rocks. Eds. M. Lehtinen, P. A. Nurmi, O. T. Rämö. Precambrian geology of Finland - key to the evolution of the Fennoscandian Shield. Amsterdam: Elsevier B. V., 2005. P. 343-406.

Kikas $R$. Pressure-temperature evolution of highgrade Svecofennian gneisses near Saaremaa Shear Zone. Tartu: Univ. of Tartu, 2001. MSc. thesis. P. 1-49.

Kirs J. X-ray and optical investigation of feldspars from Estonian early platform potassium granites. Acta Comment. Univ. Tartuensis. 1986. Vol. 759. P. 3-19. (In Russian)

Kirs J., Petersell V. Age and geochemical character of plagiomicrocline granite veins in the Abja gabbro-dioritic massif. Acta Comment. Univ. Tartuensis. 1994. Vol. 972. P. 3-15.

Kirs J., Rämö O. T., Haapala I. Anorogenic magmatic rocks in Estonian crystalline basement. Proceed. Estonian Acad. Sci., Geol. 2004. Vol. 53, no. 3. P. 210-225.

Kivisilla J. Geochemical features in crystalline basement of Estonia: PhD (Cand of Geol.-Min.) thesis. Minsk: IGIG, 1987. P. 1-340. (In Russian)

Klein V. M. Metamorphic complex of the Svecofennian Belt in Northern Estonia: PhD (Cand. of Geol.-Min.) thesis. Tallinn: Acad. Sci., Estonian SSR, 1986. (In Russian)

Koistinen T. (ed.). Precambrian basement of the Gulf of Finland and surrounding area. Map 1:1000000. Espoo: Geol. Survey of Finland, 1994.

Koistinen T. (ed.). Explanation to the Map of Precambrian basement of the Gulf of Finland and surrounding area I:I 000000 . Geol. Survey of Finland. Special Paper. 1996. Vol. 21. P. $1-141$

Konsa M. Typomorphic variations of zircon in the crystalline basement of Estonia. Proceed. Estonian Acad. Sci., Geol. 1986. Vol. 35. P. 1-9.

Konsa M., Puura V. Provenance of zircon of the lowermost sedimentary cover, Estonia, East-European
Craton. Bull. Geol. Society of Finland. 1999. Vol. 71. P. 253-273.

Koppelmaa H., Klein V., Puura V. Metamorphic complexes of the crystalline basement of Estonia. Eds. Dagelaiskiy V., Bondarenko L. Metamorphic complexes of basement of Russian Platform. Leningrad: Nauka, 1978. P. 43-76. (In Russian).

Koppelmaa H. (ed.) Geological map of the crystalline basement of Estonia. Scale 1:400 000. Tallinn: Geol. Survey of Estonia, 2002.

Kurhila M., Mänttäril., Vaasjoki M., RämöO.T., Nironen $\mathrm{M}$. U-Pb geochronological constraints of the late Svecofennian leucogranites of southern Finland. Precambrian Res. 2011. Vol. 190. P. 1-24.

Kuuspalu T. Rapakivi granites of the crystalline basement of Estonia. Acta Comment. Univ. Tartuensis. 1975 Vol. 359. P. 76-141. (In Russian)

Lahtinen R. Crustal evolution of the Svecofennian and Karelian domains during 2.1-1.79 Ga, with special emphasis on the geochemistry and origin of 1.93-1.91 Ga gneissic tonalites and associated supracrustal rocks in the Rautalampi area, central Finland. Geol. Surv. Finl. Bull. 1994. Vol. 378. P. 1-128.

Lahtinen R., Huhma H., Kontinen A., Kohonen J., Sorjonen-Ward $P$. New constraints for the source characteristics, deposition and age of the 2.1-1.9 Ga metasedimentary cover at the western margin of the Karelian Province. Precambrian Res. 2010. Vol. 176. P. 77-93.

Linari A. A. Report on Diamond Drilling near Jõhvi. Proceed. Tallinn Univ. Tech. 1940. Vol. 15. (In Estonian).

Luha A. Earth resources in ESSR. Concluding overview of geological appliances. Tartu: Teaduslik Kirjandus, 1946. P. 1-176. (In Russian)

Mansfeld J. Age and $\varepsilon_{\mathrm{Nd}}$ constraints on the Palaeoproterozoic tectonic evolution in the Baltic Sea region. Tectonophysics. 2001. Vol. 339. P. 135-151.

Melezhik V. A., Hanski E. J. Palaeotectonic and Palaeogeographic Evolution of Fennoscandia in the Early Palaeoproterozoic. Eds. Melezhik V. A., Prave A. R., HanskiE. J., FallickA. E., LeplandA., KumpL.R., Strauss $H$. Reading the Archive of Earth's Oxygenation. Berlin, Heidelberg: Springer-Verlag, 2012. P. 111-178.

Niin M. Svecofennian granitoids of the crystalline basement of Estonia: classification on the basis of geological structure, mineral and chemical composition. Eesti Geoloogiakeskuse Toimetised. 1997. Vol. 7. P. 4-40.

Niin M. Non-acid igneous rocks of the crystalline basement of Estonia. Eesti Geoloogiakeskuse Toimetised. 2002. Vol. 10. P. 4-19.

Nironen $M$. The Svecofennian Orogen: a tectonic model. Precambrian Res. 1997. Vol. 86. P. 21-44.

Nironen $M$. Proterozoic orogenic granitoid rocks. Eds. Lehtinen M., Nurmi P. A., Rämö O. T. Precambrian Geol. of Finland - Key to the Evolution of the Fennoscandian Shield. Amsterdam: Elsevier, 2005. P. 443-480.

Oja T., Ellmann A., Märdla S. Gravity anomaly field over Estonia. Est. J. Earth Sci. 2019. Vol. 68 P. 55-75.

Öpik $A$. Über Magnetometrie und die Geologie des Urgebirges von Estland. Tartu: Tartu University, 1942. Manuscript.

Park A. F. Continental growth by accretion: a tectonostratigraphic analysis of the evolution of the western 
and central Baltic Shield, 2.5 to $1.75 \mathrm{Ga}$. Geol. Soc. Am. Bull. 1991. Vol. 103. P. 522-537.

Peive A. V., Bogdanov A. A., Khain V. E. International tectonic map of Europe and adjacent areas. Scale 1:2500 000. IGC/CGMW, 1979.

Petersell V. Geological and metallogeny features of the crystalline basement of the southern slope of the Baltic Shield. Tallinn: ENSV TA GI, 1976. P. 1-28. (In Russian)

Petersell V. On the geological age of the crystalline basement of the southern slope of the Baltic Shield (SSBS). Eesti Geoloogiakeskuse Toimetised. 1991. Vol. 1. P. 25-26.

Petersell V. The age of plagiomicrocline granites in the crystalline basement of Estonia. Symposium on the Svecofennian Domain and Annual meeting of IGCP-275. 1993. P. 46.

Petersell V., Levchenkov O. On the geological structure of the crystalline basement of the southern slope of the Baltic Shield. Acta Comment. Univ. Tartuensis. 1994. Vol. 972. P. 16-39.

Petersell V., Talpas A., Põldvre A. Report of the exploration of Precambrian iron ore formation. Tallinn: Geol. Survey of Estonia, 1985. EGF 4159. P. 1-129. (In Russian)

Petersell V., Kivisilla J., Pukkonen E., Põldvere A., Täht $K$. Ore and mineralization indications of sedimentary and crystalline rocks in Estonia. Tallinn: Geol. Survey of Estonia, 1991. EGF 4523. P. 1-284. (In Russian)

Puura V. K-Ar isotopic age of crystalline basement of the Baltic States. Proceed. Estonian Acad. Sci., Chem. Geol. 1974. Vol. 23. P. 39-50.

Puura V. (ed.). Geological map of the crystalline basement of the Soviet Baltic Republics. Moscow, 1980.

Puura V., Floden T. Subjotnian igneous structures in the Svecofennian Domain of the Baltic region. GFF. 1996. Vol. 118. P. A22-A23.

Puura V., Floden T. Rapakivi-granite - anorthosite magmatism - a way of thinning and stabilisation of the Svecofennian crust, Baltic Sea Basin. Tectonophysics. 1999. Vol. 305. P. 75-92.

Puura V., Floden T. Rapakivi - related basement structures in the Baltic Sea area; a regional approach. GFF. 2000. Vol. 122. P. 257-272.

Puura V., Huhma H. Palaeoproterozoic age of the east baltic granulitic crust. Precambrian Res. 1993. Vol. 64. P. 289-294.

Puura V., Koppelmaa H. Exploration results of crystalline basement. Tallinn: Geol. Survey of Estonia, 1967. EGF 2982. (In Russian)

Puura V., Kuuspalu T. Ore occurrences in crystalline basement of Uljaste and Jõhvi area. 1:500000. Map of metallogeny vol III. Tallinn: Geol. Survey of Estonia, 1966. EGF 2801. P. 1-267. (In Russian).

Puura V., Kuuspalu T., Birkis A., Vasiljev B. A., Gaujus R., Koppelmaa H., Niin M. Outlines of the geological structure of Precambrian basement of Baltic States. Geol., petrology and metallogeny of crystalline min. resources of the East-European Platform. Part I. Moscow: Nedra, 1976. P. 1-208. (In Russian).

Puura V., Vaher R., Klein V., Koppelmaa H., Niin M., Vanamb V., Kirs J. Crystalline basement of Estonia. Moscow: Nauka Publ., 1983. P. 1-208. (In Russian)
Puura V., Klein V., Koppelmaa H., Niin M. Precambrian basement. Eds. A. Teedumäe, A. Raukas. Geol. and min. resources of Estonia. Tallinn: Estonian Academy Publ., 1997. P. 27-34.

Puura V., Klein V., KikasR., Konsa M., KuldkeppR., SoesooA. Svecofennian metamorphic zones in the basement of Estonia: an overview. Proceed. Estonian Acad. Sci., Geol. 2004. Vol. 53, no. 3 P. 149-164.

Rämo T., HuhmaH., Kirs J. Radiogenic isotopes of the Estonian and Latvian rapakivi granite suits: new data from the concealed Precambrian of the East European Craton. Precambrian Res. 1996. Vol. 79 P. 209-226.

Soesoo A. On the petrochemistry of the Precambrian quartz-feldspar gneisses (leptites) of Estonia and Suursaari (Hogland), Russian SSFR. Proceed. Estonian Acad. Sci., Geol. 1991. Vol. 40, no. 4. P. 129-140.

Soesoo A. Estonian porphyraceous potassium granites: petrochemical subdivision and petrogenetical interpretation. Proceed. Estonian Acad. Sci., Geol. 1993. Vol. 42. P. 97-109.

Soesoo A., Niin M. Petrographical and geochemical features of the Estonian porphyritic potassium granites. Proceed. Estonian Acad. Sci., Geol. 1992. Vol. 41. P. 93-107.

Soesoo A., Puura V., Kirs J., Petersell V., Niin M., All T. Outlines of the Precambrian basement of Estonia. Proceed. Estonian Acad. Sci., Geol. 2004a. Vol. 53. P. 149-164.

Soesoo A., Kalda J., Bons P. D., Urtson K., Kalm V. Fractality in geology: a possible use of fractals in the studies of partial melting processes. Proceed. Estonian Acad. Sci., Geol. 2004b. Vol. 53. P. 13-27.

Soesoo A., Kosler J., KuldkeppR. Age and geochemical constraints for partial melting of granulites in Estonia. Mineral. Petrol. 2006. Vol. 86. P. 277-300.

Soesoo A., Hade S. Geochemistry and age of some A-type granitoid rocks of Estonia. LITHOSPHERE 2012 Symposium (Nov. 6-8, 2012). Espoo, Finland, 2012. P. 97-101.

Taran L. N., Bogdanova S. V. The Fennoscandia-Sarmatia junction in Belarus: new inferences from a PT study. Tectonophysics. 2001. Vol. 339. P. 193-214.

Tikhomirov S. N. Geology of the crystalline basement in Leningrad oblast and Baltics. Leningrad: VSEGEI, 1966. P. 1-24. (In Russian)

TikhomirovS. N. New rapakivi granite massifs in the Baltic and Leningrad districts. Dokl. Akad. Sci. USSR. 1965. Vol. 164. P. 889-890. (In Russian)

Vaganova Z., Kadõrova M. Precambrian crystalline rocks and iron-rich quartzites based on the data of deep drill holes in Jõhvi. Tallinn: Geol. Survey of Estonia, 1948. EGF 125. (In Russian)

VaherR., Puura V., Erisalu E. Tectonics of north-eastern Estonia. Tallinn: ENSV TA GI, 1962. P. 319-336. (In Russian)

VaherR., Kuuspalu T., Puura V., Erisalu E. Setting of sulphide ore occurrences in the Uljaste area. Ed. Baukov S. S. Lithology of Paleozoic Deposits in Estonia. Tallinn: ENSV TA GI, 1964. P. 33-53. (In Russian) 
VelikoslavinskyD. A., Birkis A. P., BogatikovO. A., Bukharev V. P., Velikoslavinsky S. D., Gordiyenko L. I., Zinchenko O. V., Kivisilla J. J., Kirs J. E., Kononov Ju. V., Levitsky Ju. F., Niin M. I., Puura V. A., KhvorovM. I., Shustova L. Je. Anorthosite - rapakivigranite formation of the East European Platform. Leningrad: Nauka, 1978. P. 1-296. (In Russian)

\section{СВЕДЕНИЯ ОБ АВТОРАХ:}

\section{Соэсоо, Алвар}

профессор

Отделение геологии Института экологии и наук о Земле

Тартуского университета

50411, Тарту, Эстония

эл. почта: alvar.soesoo@gmail.com

\section{Нирги, Сиим}

геолог

Геологическая служба Эстонии

44314, Раквере, Эстония

аспирант

Отделение геологии Института экологии и наук о Земле Тартуского университета

50411, Тарту, Эстония

эл. почта: siim.nirgi@egt.ee

\section{Пладо, Юри}

старший научный сотрудник

Отделение геологии Института экологии и наук о Земле

Тартуского университета

50411, Тарту, Эстония

эл. почта: juri.plado@ut.ee
Väisänen M., Mänttäri l., Hölttä P. Svecofennian magmatic and metamorphic evolution in southwestern Finland as revealed by U-Pb zircon SIMS geochronology. Precambrian Res. 2002. Vol. 116. P. 111-127.

Received January 30, 2020

\section{CONTRIBUTORS:}

Soesoo, Alvar

Institute of Ecology and Earth Sciences

Department of Geology

Ravila Street 14A, 50411, Tartu, Estonia

e-mail: alvar.soesoo@gmail.com

\section{Nirgi, Siim}

Geological Survey of Estonia

FR. Kreutzwaldi 5, 44314, Rakvere, Estonia

Institute of Ecology and Earth Sciences

Department of Geology

Ravila Street 14A, 50411, Tartu, Estonia

e-mail: siim.nirgi@egt.ee

Plado, Jüri

Institute of Ecology and Earth Sciences

Department of Geology

Ravila Street 14A, 50411, Tartu, Estonia

e-mail: juri.plado@ut.ee 